ISSN 0258-7122 (Print), 2408-8293 (Online)

Bangladesh J. Agril. Res. 43(1): 149-157, March 2018

\title{
DETECTION OF SOIL FUNGI FROM WHEAT CULTIVATED AREA
}

\author{
R. K. SETH ${ }^{1}$, S. ALAM ${ }^{2}$ AND D. N. SHUKLA ${ }^{3}$
}

\begin{abstract}
Experiments were conducted to find out different soil fungi from wheat cultivated area during 15 April to 10 May, 2013-2014. The obtained soil fungi from wheat cultivated area were Aspergillus spp., Penicillum spp., Geotrichum spp., Gloesporium spp., Fusarium spp., Mycelia sterilia, Arthrobotrys spp., Cladosporium herbarum in district Allahabad, Various soil fungi from wheat cultivated area from Mirzapur district were which Aspergillus spp., Penicillum spp., Rizoctinia spp., Fusarium spp., Mucor spp. and In Varanasi district, various soil fungi were obtained also from wheat cultivated area which are Aspergillus spp., Penicillum spp., Rizoctinia spp., Fusarium spp., Mucor spp., Alternaria spp., Helminthosporium oryzae, and Humicola grisea. Aspergillus spp. and Penicillum spp. was common fungi presented in three different districts Allahabad, Mirzapur and Varanasi, of Uttar Pradesh.
\end{abstract}

Keyword: Soil fungi, Wheat, Uttar Pradesh

\section{Introduction}

Wheat (Triticum aestivum L.) is one of the most important cereals in the world and is part of a staple diet for nearly $35 \%$ of the world's population (Behl et al., 2006). It is grown in about 102 countries of the world covering about 220.69 million hectares of land which is $32 \%$ of the total cultivated land of the world. The area and production increased to 0.83 million hectare and 1.84 million metric tons, respectively in 2000 (Hasan, 2006).

Soil fungi play an important role as major decomposers in the soil ecosystem. There are about 75,000 species of soil fungi in the world (Finlay et al., 2007). Fungi are one of the dominant groups present in soil which strongly influence ecosystem structure and functioning and thus plays a key role in many ecological services (Orgiazzi et al., 2012). Therefore, there is a growing interest in assessing soil biodiversity and its biological functioning (Barrios, 2007).

The yield was $2.8 \mathrm{t} / \mathrm{ha}$ in 2011-12 cropping year (BBS, 2012) which is very low compared to those in the research farm level (3.5 to 5.1 t/ha) (Hasan, 2006). Coupled with many other factors, diseases also play an important role in lowering the yield (Saundersv, 1990, Badaruddin et al., 1994).

The process of decomposition is governed by the succession of fungi at various stage of decomposition (Beare, 1993; Valenzuela et al., 2001; Rai. et al., 2001; Santro et al., 2002) nutrient level of soil, crop residue and prevailing

\footnotetext{
${ }^{1-3}$ Bharagawa Agricultural Botany Laboratory, Department of Botany, University of Allahabad, Allahabad, U.P. India 211002.
} 
environmental conditions (Nikhra, 1981; Coockson et al., 1998; Cruz, et al., 2002; Simoes et al., 2002; Mc Tiernan, et al., 2003).

The current study was aimed detection of soil fungi from wheat field. The study involved isolation, identification and screening of soil fungi of fungal species prevailed Allahabad, Varanasi, and Mirzapur districts of Uttar Pradesh in India.

\section{Materials and Methods}

The present studies were carried out at Bhargava Agricultural Botany laboratory, Department of Botany, University of Allahabad, Allahabad. Soil samples were collected from wheat cultivated areas of selected sites of Allahabad, Varanasi and Mirzapur district during 15 April to 10 May 2013-2014 for detection of soil fungi.

\section{Study Area:}

Three studies area were select, first district Allahabad is situated in Southern Eastern. It lies between the parallels of $24^{\circ} 47^{\prime}$ north latitude and $81^{\circ} 19^{\prime}$ east longitudes, Second is Mirzapur District located at $25.15^{\circ} \mathrm{N}$ and $82.58^{\circ} \mathrm{E}$, and third Varanasi is situated at $25.28^{\circ} \mathrm{N}$ and $82.96^{\circ} \mathrm{E}$ in Uttar Pradesh, India. Soil taken $15 \mathrm{~cm}$ depth and put in small sterilized polythene bags for laboratory analysis.

\section{Isolation of Soil fungi:}

The samples were processed for isolation using the soil dilution plate (Waksman, 1922). The soil fungi were isolated following the soil dilution plating technique of (Jonhson et al., 1960). The moisture content of a certain amount of soil was determined and fresh soil quantities corresponding to $25 \mathrm{gm}$ of oven-dried soil were calculated (Öner, 1973). $1 \times 10^{-4}$ then dilutions of the samples were prepared (Warcup, 1955). Each soil sample was diluted to $1 \times 10^{-4}$ concentration suspension. Then, $1 \mathrm{ml}$ of the soil suspension (containing $0.0001 \mathrm{~g}$ wet soil) was drawn by pipette into a Petri dish $(90 \mathrm{~mm})$. A mixture of $25 \mathrm{ml}$ of warm, molten glucose-ammonium nitrate agar (GAN) added with Rose Bengal and streptomycin was poured over the soil suspension and the Petri dish was rotated gently to let the soil suspension mix well with the medium. Five replications were completed for each soil sample $(0.0005 \mathrm{gm}$ wet soil $)$. All the Petri dishes were incubated at room temperature $\left(26-28^{\circ} \mathrm{C}\right)$ in darkness for $3-5$ days or longer.

\section{Identification of the soil fungi:}

Fungal morphology was studied by observing colony features such as (Colour and Texture) and by staining with lacto-phenol, cotton blue and observe under compound microscope for the conidia, conidiophores and their arrangement. The 
fungi were identified with the help of literature (Nagamani and Manoharachary 2006). The colonies were counted and identified using the soil dilution plate method. The counting and identification procedure was carried out under a stereomicroscope. Then the identified colonies were transferred to Petri dishes containing agar. In the Petri dishes, different types of colonies developed. Identification of the organism was made with the help of the relevant literature (Thom and Raper 1945, Gilman 1957). For the identification of the isolates, Smith (1971) was followed. Identification of the taxa were carried out according to Hasenekoglu (1991), Subramanian (1983), Ellis (1971), Raper and Thom (1949), Raper and Fennell (1965), Zycha (1969), Samson and Pitt (1985, 2000)

\section{Screening of soil fungi}

Screening of soil fungi after each stage the ineffective isolates were excluded from further testing. Isolation of microorganisms and primary screening was done according to the method given by Vega et al. (2012). Various soil fungi recorded from different three districts viz. Allahabad, Mirzapur and Varanasi.

\section{Results and Discussion:}

The results obtained of different three district screening of soil fungi wheat cultivated area from the analyses 10 blocks of soil through soil dilution plate methods to determine the screening of soil fungi. Different soil fungi were recorded from wheat cultivated areas Aspergillus spp., Penicillum spp., Geotrichum spp.. Gloesporium spp., Fusarium spp., Mycelia sterilia, Arthrobotrys spp., Cladosporium herbarum. In which Aspergillus spp. and Penicillum spp. common soil fungi recorded of district Allahabad in (Table: 1)

Table 1. Isolation and identification of soil fungi from wheat cultivated area in district Allahabad

\begin{tabular}{|c|c|c|}
\hline S.No. & Blocks & Isolated Fungi \\
\hline 1. & \multirow{4}{*}{$\begin{array}{c}\text { Bahadurpur } \\
\text { Holagarh, Pratappur, } \\
\text { Phulpur, } \\
\text { Saidabad, } \\
\text { Handia, } \\
\text { Meja, } \\
\text { Manda, } \\
\text { Koroan } \\
\text { Saidabad }\end{array}$} & Aspergillus sp. \\
\hline \multirow{3}{*}{2.} & & $\begin{array}{c}\text { Aspergillus oryzea (Ahlburg Cohn) } \\
\text { Aspergillus flavus (Link) } \\
\text { Aspergillus variecolor (Thom and Church) } \\
\text { Aspergillus ochraceus (Withelm) } \\
\text { Aspergillus niveus (Blotch) }\end{array}$ \\
\hline & & Penicillum Sp. \\
\hline & & $\begin{array}{c}\text { Penicillum variabil (Sopp.) } \\
\text { Penicillum citrinum (Thom) } \\
\text { Penicillum notatum (Westling) } \\
\text { Penicillum steckii (Zaleski) } \\
\text { Penicillum Spp.(Perithecial) }\end{array}$ \\
\hline
\end{tabular}




\begin{tabular}{|c|c|c|}
\hline S.No. & Blocks & Isolated Fungi \\
\hline 3. & & Geotrichum spp. \\
\hline 4. & & Gloesporium spp. \\
\hline 5. & & Fusarium spp. (Sterile) \\
\hline 6. & & Mycelia sterilia (Four) \\
\hline 7. & & Arthrobotrys spp. \\
\hline 8. & & Cladosporium herbarum (Persoon) \\
\hline
\end{tabular}

The five Aspergillus species were recorded viz. Aspergillus oryzea, Aspergillus flavus, Aspergillus variecolor, Aspergillus ochraceus, Aspergillus niveus where as the five Penicillum speciese were recorded viz. Penicillum variabil, Penicillum citrinum, Penicillum notatum, Penicillum steckii, Penicillum Sp, in Allahabad district. Saksena, and Sarbhoy et al. (1962) also were recorded soil fungi in Allahabad district.

In the experiment detection of soil fungi from wheat cultivated area consists of 10 blocks in district Mirzapur. The soil fungi were recorded from wheat cultivated area are Aspergillus spp., Penicillum spp., Rizoctinia spp., Fusarium spp., Mucor spp. Aspergillus spp. Penicillum spp. and Fusarium spp., were common soil fungi recorded. (Table 2).

Table 2. Isolation and identification of soil fungi from wheat cultivated area in district Mirzapur.

\begin{tabular}{|c|c|c|}
\hline S. No. & Blocks & Isolated Fungi \\
\hline \multirow[t]{9}{*}{1} & \multirow{17}{*}{$\begin{array}{l}\text { Chhanvey } \\
\text { Haliya } \\
\text { Jamalpur } \\
\text { Kon } \\
\text { Lalganj } \\
\text { Madihaon } \\
\text { Majhawan } \\
\text { Narainpur } \\
\text { Rajgarh } \\
\text { Skhdi }\end{array}$} & Aspergillus sp. \\
\hline & & Aspergillus niger (Tiegh) \\
\hline & & Aspergillus flavus (Link) \\
\hline & & Aspergillus oryzea (Ahlburg Cohn) \\
\hline & & Aspergillus luchuensis (Inui) \\
\hline & & Aspergillus terreus (Thom) \\
\hline & & Aspergillus variecolor (Thom and Church) \\
\hline & & Aspergillus awamori (Nakazawa) \\
\hline & & Aspergillus niveus (Blotch) \\
\hline \multirow[t]{6}{*}{2} & & Penicillum Sp. \\
\hline & & Penicillum funiculosum (Thom) \\
\hline & & Penicillum frequentans (Westling) \\
\hline & & Penicillum steckii (Zaleski) \\
\hline & & Penicillum Sp.(Perithecial) \\
\hline & & Penicillum variabil (Sopp.) \\
\hline \multirow[t]{2}{*}{3} & & Rizoctinia Sp. \\
\hline & & Rizoctinia oryzae (Went and Geerl.) \\
\hline
\end{tabular}




\begin{tabular}{|c|c|c|}
\hline S. No. & Blocks & Isolated Fungi \\
\hline & & Rizoctinia cohnii (Berl. And de Toni) \\
\hline \multirow[t]{2}{*}{4} & & Fusarium sp. \\
\hline & & $\begin{array}{c}\text { Fusarium sp. (Sterile) } \\
\text { F,usarium avenaceum (Fr.) } \\
\text { Fusarium oxysporium (Schlect. Ex Fr.) } \\
\text { Fusarium javanicum (Koord) }\end{array}$ \\
\hline \multirow[t]{2}{*}{5} & & Mucorsp. \\
\hline & & $\begin{array}{c}\text { Mucor fragilis (Bain) } \\
\text { Mucor jansseni (Lendner) }\end{array}$ \\
\hline
\end{tabular}

The eight Aspergillus speciese were recorded viz. Aspergillus niger, Aspergillus flavus, Aspergillus oryzea, Aspergillus luchuensis, Aspergillus terreus, Aspergillus variecolor, Aspergillus awamori, Aspergillus niveus, where as the five Penicillum speciese were rcorded viz. Penicillum funiculosum, Penicillum frequentans, Penicillum steckii, Penicillum Spp, Penicillum variabil, the two Rizoctinia spp were recorded i.e. Rizoctinia oryzae, Rizoctinia cohnii, four Fusarium spp. were recorded of Fusarium spp., Fusarium avenaceum, Fusarium oxysporium, Fusarium javanicum. The two mucor speciese were recorded i.e. Mucor fragilis, and Mucor jansseni in district Mirzapur. Saksena, and Sarbhoy et al. (1966) also finding these fungi in Mirzapur district.

In district Varanasi, detection of soil fungi from wheat cultivated area consists of 8 blocks. The results were obtained of soil fungi from wheat cultivated area are Aspergillus spp., Penicillum spp., Rizoctinia spp., Fusarium spp., Mucor spp., Alternaria spp., Helminthosporium oryzae, and Humicola grisea, In which Aspergillus spp., Penicillum spp. and Fusarium spp. were common soil fungi found. in (Table: 3 ).

Table 3. Isolation and identification of soil fungi from wheat cultivated area in district Varanasi.

\begin{tabular}{|c|c|c|}
\hline S No. & Blocks & Isolated Fungi \\
\hline 1 & Arajiline & Aspergillus sp. \\
\hline \multirow{1}{*}{1} & Baragavon & Aspergillus niger (Tieghem) \\
& Chiraigaon & Aspergillus flavus (Link) \\
& Cholapur & Aspergillus luchuensis (Inui) \\
& Harhua & Aspergillus terreus (Thom) \\
& Kashi Vidya Peeth & Aspergillus variecolor (Thom and Church) \\
& Pindra & Aspergillus awamori (Nakazawa) \\
& Sewapuri & Aspergillus niveus (Blotch) \\
& & Aspergillus sydowi (Bainier \& Sastary) \\
\hline
\end{tabular}




\begin{tabular}{|c|c|c|}
\hline S No. & Blocks & Isolated Fungi \\
\hline \multirow[t]{2}{*}{2} & & Penicillum Sp. \\
\hline & & $\begin{array}{c}\text { Penicillum funiculosum (Thom) } \\
\text { Penicillum frequentans (Westling) } \\
\text { Penicillum steckii (Zaleski) } \\
\text { Penicillium rubrum (Stoll) } \\
\text { Penicillium chrysogenum (Stoll) }\end{array}$ \\
\hline \multirow[t]{2}{*}{3} & & Rizoctinia sp. \\
\hline & & Rizoctinia oryzae (Went and Geerl.) \\
\hline \multirow[t]{2}{*}{4} & & Fusarium sp. \\
\hline & & $\begin{array}{c}\text { Fusarium semitectum (Berkeley \& Revenel) } \\
\text { Fusarium oxysporium (Schlechtendahl) } \\
\text { Fusarium javanicum (Koord) }\end{array}$ \\
\hline \multirow[t]{2}{*}{5} & & Mucorsp. \\
\hline & & Mucor racemosus (Fresenius) \\
\hline \multirow[t]{2}{*}{6} & & Alternaria sp. \\
\hline & & $\begin{array}{r}\text { Alternaria alternata } \text { (Fr.) Keissler } \\
\text { Alternaria solani (Sorauer) } \\
\text { Alternaria claymydospora }\end{array}$ \\
\hline 7 & & Helminthosporium oryzae (Sacc.) \\
\hline 8 & & Humicola grisea (Traaen) \\
\hline 9 & & Pythium aphanidermatum (Edson) Fitzpatrick \\
\hline
\end{tabular}

The eight Aspergillus spp. were recorded viz. Aspergillus niger, Aspergillus flavus, Aspergillus luchuensis, Aspergillus terreus, Aspergillus variecolor, Aspergillus oryzea, Aspergillus luchuensis, Aspergillus terreus, Aspergillus variecolor, Aspergillus awamori, Aspergillus niveus, Aspergillus sydowi spp., where as the five Penicillum spp were recorded viz. Penicillum funiculosum, Penicillum frequentans, Penicillum steckii, Penicillium rubrum Penicillium chrysogenum spp., one Rizoctinia sp was recorded i.e. Rizoctinia oryzae, Three Fusarium sp. were recorded viz. Fusarium semitectum, Fusarium oxysporium, Fusarium javanicum, and one Mucor speciese i.e. Mucor racemosus, three Alternaria sp. were recorded Alternaria alternata, Alternaria solani, and Alternaria claymydospora were recorded from wheat cultivated area in Varanasi district.

\section{Conclusion:}

The two common soil fungi were obtained Aspergillus spp. and Penicillum spp. in three different districts at Allahabad, Mirzapur and Varanasi, of Uttar Pradesh in India. 


\section{Acknowledgements}

We are thankful to my sincerely Supervisor Prof. D.N. Shukla Department of Botany, University of Allahabad, Allahabad, India for Providing Laboratory Facilities and I also thanks to my friend Shah Alam for views and opinions expressed in this article.

\section{Reference:}

Badaruddin, M., D. A. Saunders, A. B. Siddique, M. A. Hossain, M. U. Ahmed, M. M. Rahman, and S. Parveen. 1994. Determining yield constraints for wheat production in Bangladesh. In: Saunders, D. A. and G. P. Hettel eds. Wheat Heat-Stressed Environments: Irrigated Day Areas and Wheat Farming Systems CIMMYT, Mexico, D. F. 265-271 Pp.

Barrios, E. 2007. Soil biota, ecosystem services and land productivity. Ecological Economics. 64(2):269 285.

BBS. 2012. Hand book of Agricultural Statistics January'1994, sector monitoring unit, Ministry of Agriculture, Government of Bangladesh.

Beare, M. H., B. R. Pohlad, D. H. Wright and D. C. Coleman. 1993. Residue placement and fungicide effects on fungal communities in conventional and no-tillage soils Soil Science. Society of America Journal 57: 392-399.

Behl, R. K., N. Narula, M. Vasudeva, A. Sato, T. Shinano and M. Osaki. 2006. Harnessing wheat genotype $\times$ Azotobacter strain interactions for sustainable wheat production in semi-arid tropics. Tropics 15: 121-133.

Coockson, W. R., M. H. Beare and P. E. Wilson. 1998. Effect of prior Crop residue Management decomposition. Applied Soil Ecology 7: 179-188.

Cruz, A. G., S. S. Gracia, F. J. C. Rojas and A. I. O. Ceballos. 2002. Foliage decomposition of velvet bean during seasonal drought. Interciencia 27: 625-630

Ellis, MB. 1971. Dematiaceus Hyphomycetes. Kew Surrey UK: Commonwealth Mycological Institute 608p.

Finlay, R.D. 2007. The fungi in soil, pp. 107-146. In J.D. Van Elsas, J.K. Jansson and J.T. Trevors (eds.). Modern Soil Microbiology. ed. CRC Press, New York.

Gliman, J.C. 1957. A Manual soil fungi Iowa State College Press, U.S.A.

Hasan, M. K. 2006. Yield gap in wheat production: A perspective of farm specific efficiency in Bangladesh. Ph.D. dissertation, Dept. of Agricultural Economics, BAU, Mymensingh.

Hasenekoglu, I. 1991. Toprak mikrofunguslari. Atatürk Ünv. Yay. Vol. 7. No: 689, Erzurum. Soil Microfungi (Turkish).

Johnson,L.F., E.A. Curl, J. H. Bond and. H.A. Fribourg. 1960. Methods for studying soil Mycoflora: Plant disease relationship. Burgess Publishing Co. Minneapolis. 179 Pp.

Mc Tiernan, K. B., M. M. Couteaure, B. Berg, M. P. Berg, R. C. de Anta, A. G. W. Kratz, P. Pirussi, J. Remacle and V. Dc. S. Amalia. 2003. Changes in chemical composition of Pinus sylvestris needle decomposition along a European coniferous forest climate transect. Soil Biology and Biochemistry 35: 801- 812. 
Nagamani K. I. K. and C Manoharachary. 2006. Hand book of soil fungi. I.K. International Pvt. Ltd.

Nikhra, K. M. 1981. Studies on fungi from Jabalpur soils with special reference to litter decomposition. Ph.D. Thesis, Jabalpur University, India

Öner, M. 1973. Atatürk Üniversitesi Erzurum Çiftlioi, Eoerli Da kuzey yamac ve Trabzon-Hopa sahil fleridi mikrofungus floras〉 ile ilgili bir araflt»rma. Ankara: Atatürk Üniv. Yay>nlar», No.158. 71P.

Orgiazzi A, E. Lumini, R. H. Nilsson, M. Girlanda and A. Vizzini. 2012. Unravelling Soil Fungal Communities from Different Mediterranean Land- Use Backgrounds. PLoS ONE 7(4): e34847.

Rai, J. P., A. Sinha and S. R. Govil. 2001. Litter decomposition mycoflora of rice straw. Crop. Science 21: 335-340.

Raper K. B. and C. Thom. 1949. A Manual of the Penicillia. Baltimore: Williams and Wilkins Company. 875P.

Raper K. B. and D. I. Fennell. 1965. The Genus Aspergillus. Baltimore: Williams and Wilkins Company. 685P.

Saksena R.K., F. N. I. Krishna Nand and A.K. Sarbhoy. 1962. Ecology of the soil fungi Uttar Pradesh. Vol.29, B. NO. P. 207-224.

Saksena, R.K.; F.N.I. Krishna Nand and A. K. Sarbhoy. 1966. Ecology of the soil fungi Uttar Pradesh. Vol.33, B. NOS. 5\&6, P. 298-306.

Samson, R. A. and J. I. Pitt. (Eds.). 1985. Advances in Penicillium and Aspergillus Systematics. Plenum Press: New York and London. 483P.

Samson, R. A. and J. I. Pitt. 2000. Integration of Modern Taxonomic Methods for Penicillium and Aspergillus Classification. Amsterdam: Harwood Academic Publishers. 510P.

Santro, A. V. de, F. A. Rutigliano, B. Berg, A. Fioretto, G. Puppi and A. Alfuni. 2002. Fungal mycelium and decomposition of needle litter in three contrasting coniferous forests. Acta Oecologia 23: 247-259

Saunders, D. 1990. Report of an on farm survey: Dinajpur District. Monograph no. 6 Wheat Research Institute Bangladesh Agricultural Research Institute, Nashipur, Dinajpur.

Simoes, M. P., M. Madeira and L. Gazariani. 2002. Decomposition dynamics and nutrient release of Cistus salvifolius L. and Cistus ladanifer L. leaf litter. Revista de Ciencias Agrarias 25: 508-520.

Smith, G. 1971. An Introduction to Industrial Mycology. London: Edward Arnold Ltd. $390 \mathrm{P}$.

Subramanian, CV. 1983. Hyphomycetes Taxonomy and Biology. London: Academic Press. 502P.

Thom, C. and K. B. Raper. 1945. A Manual of Aspergilli and Wilkins Co. Baltimore. Md., USA. 
Valenzuela, E., S. Leiva and R. Godoy. 2001. Seasonal variation and enzymatic potential of micro fungi associated with the decomposition of Northofagus pumilio leaf litter. Revista Chilena de Historia Natural 74: 737-749.

Vega, K, G. K. Villena, V H Sarmiento, Y Ludena, N Vera and M G. Correa. 2012. Production of Alkaline Cellulase by Fungi Isolated from an Undisturbed Rain Forest of Peru. Biotechnology Research International .PMC 934325.

Waksman, SA. 1922. A method of counting the number of fungi in the soil. J Bacteriol 7: 339-341.

Warcup, J. H. 1955. On the origin of colonies of fungi developing on soil dilution plates. Trans Brit Mycol Soc, 38: 298-301

Zycha, H., R. Siepmann and G. Linneman. 1969. Mucorales. Lehre: Stratuss and Cramer Gmbh. 347P. 
